\title{
Peningkatan Aktivitas dan Hasil Belajar Siswa Melalui Penggunaan Media Audio Visual Pada Materi Sistem Gerak
}

\author{
Hayati Mukaromah \\ Madrasah Tsanawiyah Negeri 2 Ponorogo \\ Jl. Soekarno Hatta No.381, Kec. Ponorogo, Kabupaten Ponorogo, Jawa Timur 63412 \\ *Email: hayatimukaromah28121971@gmail.com
}

\begin{abstract}
Abstrak
Tujuan dari penelitian ini adalah untuk mendeskripsikan penigkatan aktivitas belajar siswa dan peningkatan pemahaman siswa pada materi sistem gerak melalui media audio-visual. Rancangan penelitian ini menggunakan rancangan Penelitian Tindakan Kelas yang dilakukan dalam tiga siklus yaitu siklus I, sikuls II, dan siklus III. Subyek dalam penelitian ini adalah seluruh siswa kelas VIII K MTsN 2 Ponorogo dengan jumlah 27 siswa. Aktivitas belajar siswa yang diamati dalam penelitian ini yaitu aktivitas visual, aktivitas berbicara, aktivitas mendengarkan, aktivitas menulis, aktivitas mental, dan aktivitas emosi. Instrumen yang digunakan dalam penelitian ini adalah lembar observasi kegiatan siswa dan soal tes tertulis. Analisis data aktivitas siswa dilakukan melalui analisis deskriptif, sedangkan data hasil belajar siswa dianalisis menggunakan aplikasi anates. Hasil penelitian menunjukkan bahwa pembelajaran menggunakan media audio-visual dapat meningkatkan aktivitas belajar siswa dari siklus I hingga siklus III, yaitu pada siklus I 56,58\%, siklus II 58,9\% dan siklus III $65,32 \%$. Hasil belajar siswa juga mengalami peningkatan ditunjukkan dengan meningkatnya jumlah siswa yang memperoleh nilai tuntas. Pada siklus I, terdapat 15 siswa memperoleh nilai tuntas, pada siklus II terdapat 21 siswa memperoleh nilai tuntas,dan pada siklus III terdapat 25 siswa yang memperoleh nilai tuntas. Berdasarkan hasil penelitian tersebut dapat disimpulkan bahwa penggunaan media audio visual pada materi sistem gerak dapat meningkatkan aktivitas belajar siswa dan hasil belajar siswa.
\end{abstract}

Kata kunci: aktivitas belajar, audio-visual, hasil belajar, sistem gerak

\begin{abstract}
This study aims to describe increasing student learning activities and increasing student understanding of the motion system material through audio-visual media. This research design uses a Classroom Action Research design which is carried out in three cycles, namely cycle I, cycle II, and cycle III. The subjects in this study were all students of class VIII room K MTsN 2 Ponorogo with a total of 27 students. Student learning activities observed in this study were visual activities, oral activities, listening activities, writing activities, mental activities, and emotional activities. The instruments used in this study were student activity observation sheets and written test questions. Analysis of student activity data was carried out through descriptive analysis, while student learning outcomes data were analyzed using the anates application. The results showed that learning using audio-visual media can increase student learning activities from cycle I to cycle III, namely in cycle I $56.58 \%$, cycle II $58.9 \%$ and cycle III $65.32 \%$. Student learning outcomes also increased as indicated by the increasing number of students who obtained complete scores. In the first cycle, there are 15 students who get a complete score, in the second cycle there are 21 students who get a complete score, and in the third cycle there are 25 students who get a complete score. Based on the results of these studies, it can be concluded that the use of audio-visual media in the motion system material can improve student learning activities and student learning outcomes.
\end{abstract}

Keywords: learning activity, audio-visual, leraning outcomes, motion system

\section{PENDAHULUAN}

Kualitas pembelajaran di dalam kelas ditentukan oleh beberapa faktor, di antaranya yaitu kurikulum, guru, model pembelajaran, sarana dan prasarana, serta media pembelajaran. Ketercapaian hasil belajar pada ranah pengetahuan, sikap dan keterampialn tidak hanya dipengaruhi oleh model dan metode pembelajaran yang diterapkan, tetapi juga dipengaruhi oleh media pembelajaran yang bisa membantu keterlaksanaan proses belajar mengajar. (Almainah dkk., 2021). Penggunaan media yang tepat dapat 


\section{JPSP: Jurnal Penelitian Sains dan Pendidikan}

\section{https://e-journal.iain-palangkaraya.ac.id/index.php/mipa/}

mempermudah siswa dalam memahami materi sehingga tujuan pembelajaran lebih mudah tercapai. Berikutnya, penggunaan media pembelajaran secara kreatif dan inovatif akan memperbesar kesempatan bagi siswa untuk belajar lebih banyak, pemahaman terhadap materi menjadi lebih baik, dan meningkatkan kemampuan sesuai dengan tujuan pembelajaran yang telah ditetapkan (Devi dkk., 2018).

Azhar (2010) menyatakan bahwa media pembelajaran sangat diperlukan dalam proses belajar mengajar karena membuat proses pembelajaran menjadi lebih menarik dan dapat memacu siswa untuk belajar dengan lebih semangar, meningkatkan keterampilan berpikir dan memahami siswa, menanamkan rasa percaya diri dan mempermudah siswa dalam memahami materi yang diajarkan khususnya pada mata pelajaran Ilmu Pengetahuan Alam yang merupakan mata pelajaran dengan cakupan materi yang luas dan kompleks. Salah satu media yang digunakan dalam pembelajaran yang diprediksikan dapat meningkatkan hasil belajar dan aktivitas belajar siswa adalah media audio visual. Sukiman (2012) menerangkan bahwa media audio visual merupakan salah satu media pembelajaran berbasis teknologi yang dapat digunakan untuk mengoptimalkan proses pembelajaran, dikarenakan bisa membantu siswa yang masih kurang dalam memahami materi pelajaran yang bersifat abstrak atau sulit diamati dalam dunia nyata. Dalam hal ini media audio visual dapat digunakan sebagai alat untuk mempresentasikan sebuah konsep, mempertegas materi pembelajaran dan memberikan pemahaman yang lebih kongkrit.
Berdasarkan hasil observasi di MTsN 2 Ponorogo diperoleh informasi bahwa pada umumnya guru Biologi (IPA) masih melaksanakan pembelajaran yang berorientasi pada guru. Dalam pembelajaran, guru lebih aktif dibandingkan dengan peserta didik, keaktifan peserta didik dalam proses pembelajaran masih sangat rendah. Dalam proses belajar mengajar, guru hanya menjelaskan materi pelajaran dengan menggunakan metode ceramah dan diskusi menggunakan buku pegangan siswa. Dalam mata pelajaran IPA, buku pegangan hanya berisi ringkasan materi pokok, salah satunya adalah materi sistem gerak. Pada materi sistem gerak, ringkasan materi dilengkapi dengan gambar-gambar penjelas akan tetapi gambargambar tersebut kurang menarik karena tidak begitu jelas dan juga tidak bewarna (hitamputih). Penggunaan media pendukung masih jarang digunakan khususnya media audio-visual.

Berikutnya, hasil wawancara dengan guru bidang studi IPA di MTsN 2 Ponorogo diketahui bahwa hasil ujian pada tahun ajaran terakhir menunjukkan bahwa nilai ratarata biologi di kelas VIII khususnya pada materi sistem gerak yaitu 59,80. Hal ini membuktikan bahwa rata-rata siswa belum mencapai nilai KKM yang telah ditetapkan di sekolah tersebut, yaitu 65. Hasil wawancara berikutnya dengan salah seorang siswa kelas VIII, materi Sistem Gerak dianggap sulit untuk dipahami karena terdapat beberapa sub materi yang mengharuskan siswa untuk bisa mengidentifikasi jenis otot, mendeskripsikan struktur otot, mengetahui fungsi otot, 


\section{JPSP: Jurnal Penelitian Sains dan Pendidikan}

\section{https://e-journal.iain-palangkaraya.ac.id/index.php/mipa/}

menjelaskan letak, dan cara kerjanya. Pada proses pembelajaran, materi ini hanya diajarkan menggunakan buku paket sehingga siswa hanya diajarkan teori tanpa mengetahui persis bagaimana gambar bentuk dan letaknya dengan jelas.

Berdasarkan permasalahan tersebut, penggunaan media pembelajaran yang interaktif sangat diperlukan oleh siswa. Media audio-visual bisa menjadi solusi yang ditawarkan karena tidak hanya dapat menampilkan gambar saja tetapi gambar yang disertai suara, sehingga dapat mencakup tipe siswa yang dominan auditori maupun tipe siswa yang dominan visual (Anggraini, 2015). Penggunaan media audio-visual ini dianggap mampu menarik perhatian dan memotivasi belajar para siswa yang akan berpengaruh pada hasil belajar siswa. Keberhasilan pembelajaran ditandai dengan perolehan pengetahuan, keterampilan dan sikap positif pada diri individu, sesuai dengan tujuan yang diharapkan (Mukarromah dan Julianto, 2014).

Romi (2012) menyatakan bahwa penggunaan media audio visual dapat secara efektif meningkatkan aktivitas dan hasil belajar siswa pada mata pelajaran IPA yang mencapai 94,74\% dalam tiga siklus pembelajaran. Penelitian berikutnya oleh Aris dan Sari (2021) menunjukkan bahwa penggunaan media audio visual dapat meningkatkan hasil belajar siswa yaitu $81 \%$ pada siklus II. Berdasarkan uraian latar belakang tersebut, tujuan penelitian ini adalah untuk meningkatkan aktivitas dan hasil belajar siswa melalui penggunaan media audio-visual pada materi sistem gerak kelas VIII MTs Negeri 2 Ponorogo.

\section{METODE PENELITIAN}

Jenis penelitian ini adalah Penelitian Tindakan Kelas (PTK) (Suharsimi, 2009). Penelitian Tindakan Kelas ini dilaksanakan dalam tiga siklus yaitu siklus I, siklus II, dan siklus III. Subyek dalam penelitian ini adalah peserta didik kelas VIII K MTs Negeri 2 Ponorogo sebanyak 27 peserta didik. Penentuan subyek penelitian yang digunakan oleh peneliti yaitu dengan menggunakan teknik purposif sampling. Peneliti bekerja sama dengan guru mata pelajaran IPA sebagai teman sejawat. Peneliti bertindak sebagai penyaji yang berinteraksi langsung dengan siswa di dalam kelas, sedangkan guru mata pelajaran IPA lain bertindak sebagai observer yang membantu peneliti dalam mengobservasi aktivitas belajar peserta didik. Penelitian ini terdiri atas 3 siklus, setiap siklus dalam penelitian ini terdiri dari 4 tahap yang meliputi, perencanaan, pelaksanaan tindakan, observasi, dan refleksi. Aktivitas siswa yang diamati oleh observer dalam penelitian ini yaitu aktivitas visual, aktivitas berbicara, aktivitas mendengarkan, aktivitas menulis, aktivitas mental, dan aktivitas emosi. Hasil belajar siswa yang diperoleh berupa nilai hasil belajar yang dilaksanakan di tiap akhir siklus penelitian.

Pengambilan data aktivitas belajar siswa menggunakan Lembar Observasi Aktivitas Siswa dan data hasil belajar siswa diperoleh menggunakan Lembar tes. Aktivitas siswa diobservasi melalui pengamatan langsung aktivitas siswa selama proses pembelajaran oleh dua orang observer. Data yang diperoleh melalui lembar observasi dan dokumentasi akan dianalisis dengan menggunakan analisis 


\section{https://e-journal.iain-palangkaraya.ac.id/index.php/mipa/}

deskriptif kuantitatif. Hasil belajar siswa diperoleh dengan melihat nilai rata-rata hasil belajar yang diperoleh siswa setelah pembelajaran dan akan dianalisis dengan menggunakan aplikasi anates.

\section{HASIL PENELITIAN}

Berdasarkan hasil observasi aktivitas siswa diketahu bahwa aktivitas belajar siswa pada siklus I dengan penggunaan media audiovisual pada materi sistem gerak dapat dikategorikan kurang aktif. Aktivitas-aktivitas belajar siswa secara rinci diperoleh data yaitu aktivitas visual sebesar $93,5 \%$ oleh observer 1 dan $94,4 \%$ oleh observer 2. Aktivitas berbicara, mendengarkan, mental, dan emosi memperoleh nilai yang sama antar dua observer yaitu berturut-turut 9\%, 100\%, 1.85\%, dan $100 \%$. Aktivitas menulis diperoleh persentase yang berbeda lagi antara observer 1 dan 2 yaitu $39,8 \%$ dan $29,6 \%$. Nilai rata-rata aktivitas siswa pada siklus I setelah dati dari kedua observer diakumulasi adalah 56,81\%.

Hasil observasi aktivitas belajar siswa padan siklus limenunjukkan adanya peningkatan dibandingkan hasil pengamatan aktivitas belajar siswa pada siklus I.
Peningkatan tersebut terjadi pada aktivitas visual yang memperoleh nilai $100 \%$ dari kedua observer dan aktivitas menulis yang memperoleh persentase $45.3 \%$ dari observer kedua (yang sebelumnya hanya 29.6\%). Sedangkan untuk aktivitas berbicara dan mental masih mendapatkan persentase yang sama seperti siklus I yaitu sebesar $9 \%$ dan $1.85 \%$ oleh kedua observer. Nilai rata-rata aktivitas siswa pada siklus I setelah dati dari kedua observer diakumulasi adalah $58.9 \%$.

Hasil observasi aktivitas belajar siswa pada siklus III menunjukkan adanya peningkatan sehingga aktivitas belajar siswa pada siklus ini dapat dikategorikan aktif. Peningkatan yang nyata terdapat pada aktivitas berbicara yang memperoleh persentase $21.16 \%$ dari kedua observer yang pada siklus sebelumnya hanya 9\%. Aktivitas menulis mjuga menunjukkan peningkatan yaitu menjadi $57.4 \%$ oleh observer 1 dan $59.25 \%$ oleh observer 2. Aktivitas berikutnya yang menunjukkan peningkatan yaitu aktivitas mental yang memperoleh persentase $13 \%$ oleh kedua observer. Hasil observasi aktivitas belajar siswa secara lebih rinci ditampilkan pada Tabel 1.

Tabel 1. Peningkatan aktivitas siswa pada siklus I, II, dan 3.

\begin{tabular}{lcccccc}
\hline \multirow{2}{*}{ Jenis Aktivitas } & \multicolumn{2}{c}{ Siklus I } & \multicolumn{2}{c}{ Siklus 2 } & \multicolumn{2}{c}{ Siklus 3 } \\
\cline { 2 - 7 } & O1 & O2 & O1 & O2 & O1 & O2 \\
\hline Aktivitas Visual & $93,5 \%$ & $94,4 \%$ & $100 \%$ & $100 \%$ & $100 \%$ & $100 \%$ \\
Aktivitas Berbicara & $9 \%$ & $9 \%$ & $9 \%$ & $9 \%$ & $21,16 \%$ & $20,1 \%$ \\
Aktivitas Mendengarkan & $100 \%$ & $100 \%$ & $100 \%$ & $100 \%$ & $100 \%$ & $100 \%$ \\
Aktivitas Menulis & $39,8 \%$ & $29,6 \%$ & $39,8 \%$ & $45,3 \%$ & $57,4 \%$ & $59,25 \%$ \\
Aktivitas Mental & $1,85 \%$ & $1,85 \%$ & $1,85 \%$ & $1,85 \%$ & $13 \%$ & $13 \%$ \\
Aktivitas Emosi & $100 \%$ & $100 \%$ & $100 \%$ & $100 \%$ & $100 \%$ & $100 \%$ \\
\hline Rata-rata & \multicolumn{7}{c}{$\mathbf{5 6 , 5 8 \%}$} & $\mathbf{5 8 , 9 \%}$ & \multicolumn{2}{c}{$\mathbf{6 5 . 3 2 \%}$} \\
\hline O1= Observer 1 & \multicolumn{7}{c}{} \\
O2 = observer 2 & \multicolumn{7}{c}{}
\end{tabular}




\section{JPSP: Jurnal Penelitian Sains dan Pendidikan}

\section{https://e-journal.iain-palangkaraya.ac.id/index.php/mipa/}

Berdasarkan KKM yang ditetapkan pada mata pelajaran IPA (Biologi) kelas VIII yaitu 65, maka diperoleh data hasil belajar siswa yang diperoleh melalui tes tulis dan ditampilkan pada Gambar 1. Hasil belajar siswa pada siklus I diketahui bahwa terdapat 12 mahasiswa yang memperoleh nilai belum tuntas atau sebesar $44.4 \%$ siswa tidak tuntas. Hasil tersebut juga menyebutkan bahwa $56.6 \%$ saja siswa yang memperoleh nilai tuntas. Pada siklus II diperoleh peningkatan hasil belajar siswa yaitu sebanyak 21 siswa memperoleh nilai tuntas atau sebesar $77.78 \%$. Selanjutnya pada siklus III, diperoleh peningkatan lagi pada hasil belajar siswa yaitu sebanyak 25 siswa memperoleh nilai tuntas atau sekitar 92,6\%. maka dari tabel di atas dapat diketahui bahwa pada pada siklus I terdapat 12 siswa yang tidak tuntas dan terdapat 15 siswa yang tuntas.

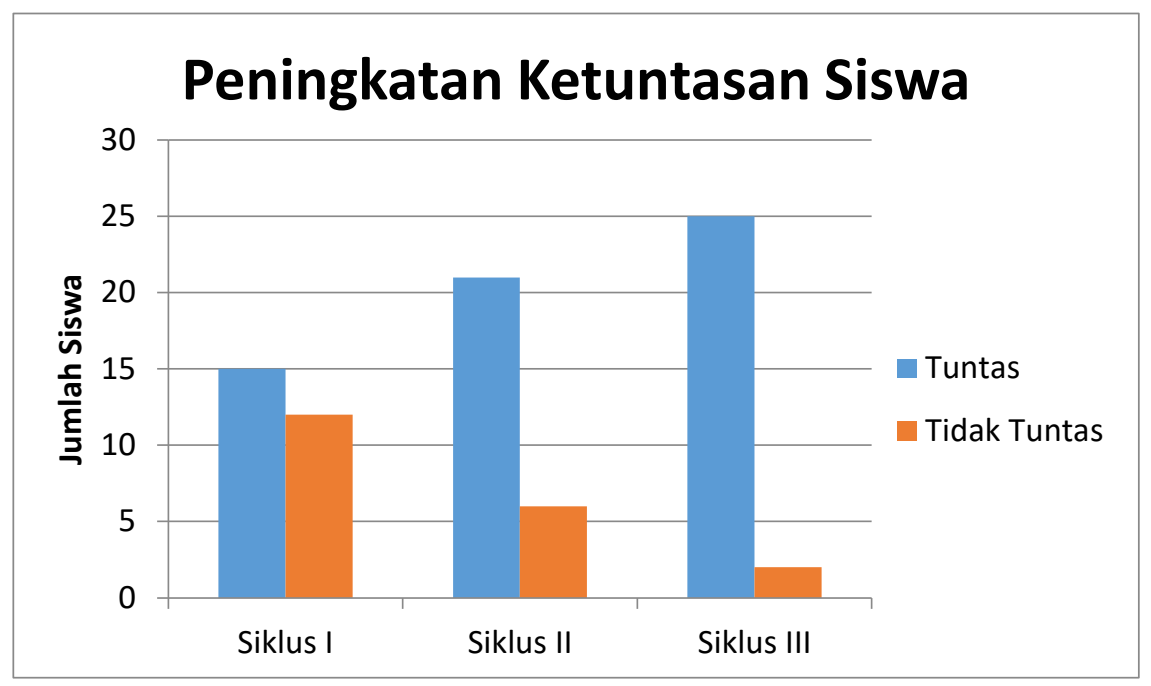

Gambar 1. Peningkatan jumlah siswa yang memperoleh nilai tuntas pada siklus I, II, dan III

\section{PEMBAHASAN}

Pada pembelajaran siklus I diperoleh hasil aktivitas bekajar siswa yang tergolong kurang aktif dan banyaknya siswa yang memperoleh nilai di bawah KKM karena terdapat kendala yaitu, siswa masih belum berani mengajukan pertanyaan sehingga hanya diperoleh persentase 9\% saja siswa yang berani. Selain itu aktivitas mental yang diukur melalui aktivitas siswa saling bertukar pendapat tentang materi yang telah dijelaskan juga masih sangat kurang karena kurangnya kemampuan berbicara siswa.
Berdasarkan tahap refleksi pada siklus I, maka dirumuskan langkah-langkah untuk mengatasi kendala-kendala tersebut agar tidak terjadi pada pembelajaran siklus II dan III yaitu peneliti harus lebih menguasai kelas dan memacu siswa agar lebih berani mengajukan pertanyaan juga memberikan tanggapan dari pertanyaan. Keberanian siswa memberi tanggapan dan mengajukan pertanyaan merupakan salah satu indikator meningkatnya aktivitas berbicara siswa. 


\section{JPSP: Jurnal Penelitian Sains dan Pendidikan}

\section{https://e-journal.iain-palangkaraya.ac.id/index.php/mipa/}

Hasil penelitian ini sejalan dengan penelitian Yulius (2014) yaitu penggunaan media audio visual berupa video dapat meningkatkan aktivitas dan hasil belajar siswa pada materi sistem gerak siswa kelas VIII sebanyak $80,95 \%$ siswa yang memperoleh nilai tuntas. Penelitian Marliah (2016) menyatakan bahwa penggunaan media audio visual berupa VCD pembelajaran pada mata pelajaran IPA dapat meningkatkan hasil belajar siswa pada siklus II sebesar 68,5\%. Penelitian berikutnya yang sejalan dengan hasil penelitian ini yaitu oleh Riswanto dan Fatmawati (2021) menunjukkan bahwa aktivitas siswa pada pembelajaran fisika secara keseluruhan dengan penggunaan media interaktif berupa adobe flash termasuk dalam kategori sangat baik dengan persentase nilai rata-rata sebesar $85,73 \%$

Hasil belajar siswa yang meningkat setelah guru menggunakan media audio visual dikarenakan saat guru menjelaskan materi peserta didik mampu menyimak dengan baik dan peserta didik termotivasi untuk mengikuti kegiatan belajar secara aktif sehingga berdampak pada peningkatan nilai hasil belajar peserta didik. Hal tersebut sesuai dengan penelitian oleh Purwono dkk (2014) yang menyebutkan bahwa dengan penggunaan media audio visual, peserta didik mendapatkan suasana pembelajaran yang baru, suasana kelas menjadi lebih interaktif, pembelajaran menjadi menarik dan peserta didik menjadi lebih lebih antusias dalam mengikuti pembelajaran.
Berdasarkan data penelitian yang telah diperoleh maka dapat diambil simpulan bahwa penggunaan media audio visual pada materi sistem gerak dapat meningkatkan aktivitas belajar siswa pada siklus III sebesar 65,32\%. Berikutnya penggunan media audio visual juga dapat meningkatkan hasil belajar siswa dibuktikan dengan meningkatnya persentase siswa yang memperoleh nilai tuntas pada siklus III yaitu sebesar 92,6\%. Berdasarkan hasil penelitian ini penggunaan media audiovisual bisa dicoba diterapkan pada materi pokok lain khususnya pada materi yang memerlukan bantuan audio visual untuk lebih memahamkan siswa.

\section{DAFTAR PUSTAKA}

Almainah, Ulva R, Hader AE. 2021. Pengaruh Media Audio Visual Terhadap Hasil Belajar Siswa Di Kelas IV SDN 06 Sitiung Pada Mata Pelajaran IPA Materi Gaya Dan Gerak. INNOVATIVE. 1(2): 5560 .

Anggraini, IA. 2015. Pengaruh Media Audio Visual terhadap Hasil Belajar Biologi Siswa pada Konsep Sistem Organisasi Kehidupan. Skripsi. Fakultas Ilmu Tarbiyah dan Keguruan UIN Syarif Hidayatullah.

Azhar A. 2010. Media Pembelajaran. Jakarta: PT Raja Grafindo Persada.

Devi C, Utari TSG, Nurkanti M. 2018. Penggunaan media pembelajaran MIVI (Media Interaktif Visual) untuk meningkatkan hasil belajar siswa pada topik sistem gerak manusia. JURNAL

BIOEDUKATIKA. 6(1): 1 - 7. 
Marliah Y. 2016. Peningkatan Hasil Belajar IPA Bagi Siswa Kelas VI Dengan Menggunakan Media Audio Visual (VCD Pembelajaran) SD Negeri Panyingkiran Kota Tasikmalaya Tahun Pelajaran 2014/2015. Jurnal Edukasi, 4(4): 413418.

Mukarromah N, Julianto. 2014. Peningkatan Hasil Belajar Siswa dengan Menerapkan Media Audio-visual Pada Pembelajaran IPA. JGPSD. 2(3): 1-4.

Purwono J, Yutmini S, Anitah, S. 2014. Penggunaan Media Audio-visual pada Mata Pelajaran Ilmu Pengetahuan Alam di Sekolah Menengah Pertama Negeri Pacitan. Jurnal Teknologi Pendidikan dan Pembelajaran, 2(2): 127-144.

Riswanto, Fatmawati S. 2021. Penerapan Model Problem Based Learning(PBL)BerbantukanProgramAdob e Flash Terhadap Kemampuan SiswaMemecahkan Masalah Materi Getaran Dan Gelombang. Jurnal Penelitian Sains dan Pendidikan. 1(1): 26-32

Romi. 2012. Peningkatan Hasil Belajar IPA dengan Media Audio-visual Kelas VIII SMP Segedong Bengkayang. Skripsi. Fakultas Keguruan Ilmu Pendidikan Universitas Tanjungpura, Pontianak.

Suharsimi. 2009. Penelitian Tindakan Kelas, Jakarta: Bumi Akasara.

Sukiman. 2012. Pengembangan Media Pembelajaran. Yogyakarta: Pedagogia.

Yulius T. 2014. Penggunaan media audiovisual pada materi sistem gerak pada manusia dalam meningkatkan minat dan hasil belajar siswa kelas VIIIB SMP Taman Dewasa Ibu Pawiyatan Yogyakarta. Skripsi. Universitas Santha Dharma, Yogyakarta. 